\title{
Evaluation Analysis on an Integrated Fare Initiative in Beijing
}

Xumei Chen and Guoxin Lin, Beijing Jiaotong University

Lei Yu, Beijing Jiaotong University and Texas Southern University

\section{Abstract}

An effective fare policy and structure will realize a reasonable combination of both public welfare and operational profit. This article presents an evaluation framework for an integrated fare initiative in Beijing. It explores a new set of 10 evaluation indices, which include public acceptance, social equity, convenience, change of subsidy, possibility of modal integration, feasibility of implementation, change of revenue, change of ridership, improvement of operation control, and change of cost. The framework is implemented by combining the method of multiple criteria fuzzy decision with the analytic hierarchy process (AHP). The article examines a survey of Beijing Public Transit System users to assess three integrated fare strategies introduced by the agency. The results from the survey are subsequently used as the input data to the proposed evaluation framework. The implementation of the proposed framework in Beijing has shown that the price level of a one-month pass ticket should be increased, while it is recommended that its price cannot be increased to the level that is close to its operation cost. The case study also shows that the proposed framework is a practical and efficient method for fare evaluation. 


\section{Introduction}

After entering the new century, many countries, especially developing countries such as China, have been facing more and more serious transportation problems. Transit congestion and declining efficiency of the entire transportation system are the combined results of the rapid increase of car ownership, simultaneous running of motor vehicles and nonmotorized transport tools on the same transportation facilities, imbalanced development of a public transport system and private transport mode, and insufficiency of the urban transportation infrastructure investment. These outcomes have resulted in great losses to the national economy. Giving priority to developing a public transport system with different capacities is becoming a fundamental policy for most cities in China today. Enhancing capacities and improving service quality are key to increasing the number of trips on public transit. Overall success is further ensured through reasonable fare structures and policies and practical fare initiatives.

Urban fare policy refers to the institutional arrangement of urban transportation pricing structure and category (Li et al. 2004). Existing urban fare policies are classified into two categories: elementary and accessorial. These categories are often combined in a city. Elementary fare policy includes single, distance-based, one-month pass, one-week pass, and one-day pass tickets; accessorial fare policy includes time-based, ride-number-based, and peak-hour-based tickets.

Fare level is one of the key factors affecting public transit ridership. Used as a lever to adjust transit trip demand and supply, fare level can play an important role in the operation of an urban transportation system. An effective fare policy and structure will realize a reasonable combination of both public welfare and operational profit (Lu 2004). In this regard, the fare policy should address both the benefit of a public transport operator, such as an urban rail transit company or a bus company, and the endurance of the rider. Improving pricing methods, establishing a multilevel fare policy system, and implementing integration of pricing of a public transport system represent the trends in fare collection practices. To ensure the success of any new pricing strategy, the ability to evaluate these strategies in an objective and quantitative manner is essential. Unfortunately, few existing theories and practices have attempted to evaluate the implementation effect of an integrated fare initiative from a comprehensive view. In this context, this article proposes a comprehensive evaluation framework to an integrated fare initiative in Beijing. The framework combines multiple criteria fuzzy decisions with the analytic hierarchy process. 


\section{Review of Fare Policy Evaluation Methodologies}

The evaluation work of a fare policy is a critical step, which should be included in the entire process of developing a fare system and structure. Specific criteria must be developed before pursuing the evaluation of fare system options and fare strategy options. The selection decision for a fare system usually is based on the results from a fare initiative evaluation. Existing methodologies on the fare initiative evaluation are summarized below.

\section{Elasticity Theory}

Products provided by the transit industry are considered quasi-public products. Fare changes follow econometric rules since demand and market elements exist. The price elasticity of demand measures the responsiveness of quantity demanded to a change in price, when all other factors are held constant. In general, elasticity that can be applied to the transportation field includes point elasticity, arch elasticity, and shrinkage ratio. Transit price sensitivity is measured using the elasticities defined as the percentage change in transit trips resulting from a 1 percent change in fare, holding constant the effects of all other determining variables (Todd 2004). This assessment method represents quantitative assessments of ridership and revenue effects with the fare changes. Curtin (1968) developed a measurement of transit ridership fare elasticity known as the Simpson-Curtin formula. This measurement postulates a fare elasticity of -0.33 ; that is, a 10 percent increase in fare would result in a 3.3 percent decrease in transit patronage. Since Curtin's original study, other studies on transit fare elasticity have also been carried out.

Major sources and techniques of developing fare elasticities, as summarized by Fleishman et al. (1996), include the following:

1. Time series analysis of the agency's historical ridership data, which often includes a regression analysis to isolate the effects of fare changes from other factors, such as service changes, employment, or fuel prices;

2. Before and after ("shrinkage") analysis for a particular fare change;

3. Use of a demand function, often on the basis of the results of stated preference surveys (i.e., asking how people would respond to various fare options and changes, or alternatively asking them to "trade off" fare changes with level-of-service changes);

4. Review of industry experience, particularly for agencies of similar size and with similar characteristics; and 
5. Use of professional judgment in adjusting figures derived from the above sources.

\section{Multiple Criteria Fuzzy Decision Theory}

Selecting a fare system and fare structure is a decision-making process that involves multiple factors. Thus, the evaluation should not only analyze one single index corresponding to a particular factor but also conduct a comprehensive analysis on all indices simultaneously. Fare initiative evaluation is a conflicting analysis process of value judgement from technological, socioeconomic, environmental, and political perspectives. In the design of a fare initiative, it is rather difficult to obtain unique, direct, and concise solutions. Therefore, the fare initiative decision involves multiple factors that should always seek compromised and acceptable alternatives, and which should be evaluated by a suitable method. Multiple criteria comprehensive evaluation provides a flexible approach to dealing with multiplefactor decision-making problems.

Fare initiative decision-making involves multiple influencing factors, most of which are difficult to quantify. In other words, the influencing factors are evaluated by qualitative indices. Although such indices cannot be measured quantitatively, their range and influencing tendency can be readily determined. That is to say, we only have fuzzy judgement on them. Therefore, the multiple criteria fuzzy comprehensive evaluation method can be applied in the fare initiative decision making. Li et al. (2004) applied this kind of evaluation method in their study on fare strategies.

A mathematical model of a fuzzy comprehensive evaluation can be expressed as follows:

When evaluating a subject, suppose that $U=\left\{u_{1}, u_{2}, \ldots, u_{m}\right\}$ and $V=\left\{v_{l}, v_{2}, \ldots\right.$, $\left.u_{n}\right\}$ are two finite "reference sets"

where:

$U \quad$ is the set of evaluation factors of fare initiative decisions; and

$V \quad$ is the set of evaluations. 
Fuzzy comprehensive evaluation of fare initiative decisions can be implemented by a fuzzy transformation:

$$
B=A \circ R
$$

where:

$A \quad$ is a fuzzy subset on $U$, which is called weight vector of $U$;
$B \quad$ is the evaluation result and is a fuzzy subset on $V$; and
$R \quad$ is a fuzzy relation on $U \times V$ :

$R=\left(r_{i j}\right)_{m \times n}$

where:
$r_{i j} \quad$ is the membership degree to $v_{j}$ from the viewpoint of factor $u_{i}$; and
$R \quad$ is induced from fuzzy mapping.

$$
f: U \rightarrow F(V)
$$

Here, $(U, V, R)$ is called the mathematical model of the fuzzy comprehensive evaluation (Ouyang et al. 2002; Ma et al. 1999).

\section{Analytic Hierarchy Process}

The analytic hierarchy process (AHP) is a decision approach designed to aid in the solution of complex multiple criteria problems in a number of application domains. By establishing a comprehensive, logical, and structural framework, AHP improves the understanding of complex decisions by decomposing the problem in a hierarchical structure. This method has been found to be an effective and practical approach in the decision-making process because of its simplicity, promising accuracy, theoretical robustness, ability to handle both tangible and intangible criteria, and capability to measure directly the inconsistency of the respondents' judgments (Atthirawong and MacCarthy 2002; Saaty 1980). Therefore, AHP is used in the proposed evaluation framework. Generally, the AHP is based on three steps: (1) decomposition of the decision problem and constructing hierarchies, (2) comparative judgment of the decision elements, and (3) synthesis of priorities. 


\section{Proposed Evaluation Framework}

An integrated fare pricing initiative may achieve a wide range of urban transportation goals, such as alleviating traffic congestion and reducing air or noise pollution. Smart card technologies make the fare pricing integration between different transit operation agencies possible. At present, the "One Card Engineering" project has been launched in many cities in China, such as Beijing, Shanghai, and Guangzhou. Critical questions are arising in terms of how to coordinate intermodal pricing among different transit operators and how to evaluate the integrated fare alternative. However, little effort has been made to address these questions. This article proposes a framework called "multiple criteria fuzzy decision combined with AHP" to evaluate the integrated fare initiative in Beijing.

\section{Proposed Framework}

In this article, a two-level structure of the hierarchy on the fare initiative evaluation model is proposed. The design methodology for evaluating the integrated fare initiative combines the multiple criteria fuzzy decision with AHP, which is implemented by executing the following five steps:

\section{Step 1. Determine Evaluation Factors Set and Index Set}

$$
U=\left\{C_{1}, C_{2}, C_{3}\right\}
$$

where:

$$
\begin{aligned}
& C_{1}=\left\{D_{1}, D_{2}, D_{3}\right\}: \\
& C_{2}=\left\{D_{4}, D_{5}, D_{6}\right\}: \text { and } \\
& C_{3}=\left\{D_{7}, D_{8}, D_{9}, D_{10}\right\}:
\end{aligned}
$$

Figure 1 shows the framework of the proposed fare initiative evaluation system. It is a hierarchical framework with three levels. The first level represents the fare initiative evaluation $U$. The second level is the evaluation criterion level, which classifies the indices according to citizen-, government-, and industry-related characteristics. The third level is the index sets, which include public acceptance, social equity, convenience, change of subsidy, possibility of modal integration, feasibility of implementation, change of revenue, change of ridership, improvement of operation control, and change of cost. The 10 indices are proposed on the basis of analyzing characteristics of both Beijing transportation development 


\section{Figure 1. The Framework of the Fare Initiative Evaluation System}

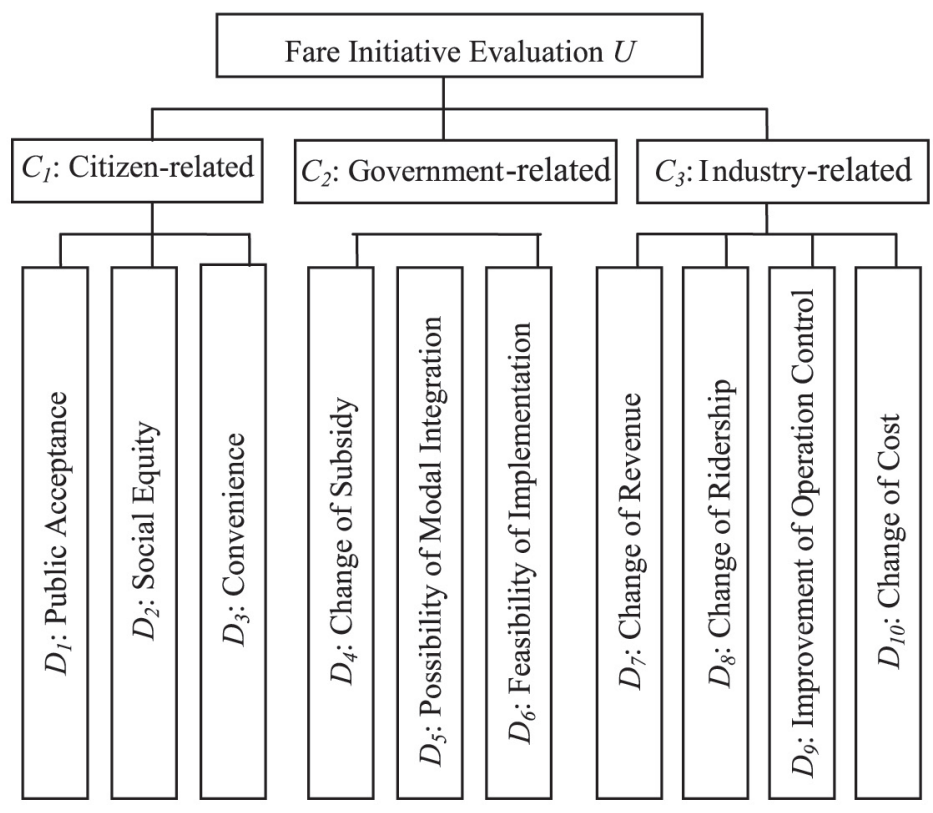

and its fare policy goal, and by expanding the evaluation indices of other transit agencies presented by Fleishman et al. (1996). More specific descriptions of the 10 indices are provided in Table 1. Compared with the four fare initiative evaluation indices proposed by Li et al. (2004) — transit company revenue, government subsidy, citizen acceptance, and fare integration-the proposed 10 indices reflect more comprehensive decision elements of the fare initiative. At the same time, the principle of concision of index sets is adopted. In Beijing, more attention must be given to the transportation disadvantaged (mostly low-income citizens) and the coordination problems between different transportation modes. As a result, indices of social equity and the possibility of modal integration are proposed.

Convenience is another important factor that concerns citizens in Beijing because there are occasional operational problems in using the smart card. Since the transit fare initiative should eventually raise transit's share in the modal split, the index of change of ridership is included. In terms of fare policy, the goal of the transit industry in Beijing is to improve operational control and operational cost. Moreover, both technological and institutional consideration should be viewed as 
Table 1. The Framework of the Fare Initiative Evaluation System

\begin{tabular}{|l|l|}
\hline \multicolumn{1}{|c|}{ Name of the Index } & \multicolumn{1}{c|}{ Description of the Index } \\
\hline Public acceptance & $\begin{array}{l}\text { Reflects the extent of public } \\
\text { acceptance/opposition to a certain fare } \\
\text { initiative }\end{array}$ \\
\hline Social equity & $\begin{array}{l}\text { Evaluates whether a certain fare initiative } \\
\text { gives consideration to transportation cost } \\
\text { affordability by different income groups }\end{array}$ \\
\hline Convenience & $\begin{array}{l}\text { Assesses whether a certain fare initiative } \\
\text { is convenient for transit users and whether } \\
\text { the fare collection facilities are easy to use }\end{array}$ \\
\hline Change of subsidy & $\begin{array}{l}\text { Reflects the extent of increase/decrease of } \\
\text { government subsidy under a certain fare } \\
\text { initiative }\end{array}$ \\
\hline $\begin{array}{l}\text { Possibility of modal } \\
\text { integration }\end{array}$ & $\begin{array}{l}\text { Reflects whether the fare initiative } \\
\text { contributes to the coordination of } \\
\text { multimodal operations, improvement of } \\
\text { connectivity between different transit } \\
\text { modes, and achievement of the urban } \\
\text { transportation vision }\end{array}$ \\
\hline $\begin{array}{l}\text { Feasibility of } \\
\text { implementation }\end{array}$ & $\begin{array}{l}\text { Assesses implementation feasibilities of a } \\
\text { certain fare initiative under specific } \\
\text { economical, technological, and facility } \\
\text { conditions }\end{array}$ \\
\hline Change of revenue & $\begin{array}{l}\text { Reflects the extent of increase/decrease of } \\
\text { fare revenues under a certain fare initiative }\end{array}$ \\
\hline Change of ridership & $\begin{array}{l}\text { Reflects the impact of mode choice of } \\
\text { travellers under a certain fare initiative }\end{array}$ \\
\hline control & $\begin{array}{l}\text { Evaluates the ability to enhance the } \\
\text { operation control of a certain fare } \\
\text { initiative, such as reducing fare } \\
\text { abuse/evasion, employee fraud, theft or } \\
\text { mishandling of fare revenue }\end{array}$ \\
\hline $\begin{array}{l}\text { Evaluates the extent of improving } \\
\text { operation cost of the transit company } \\
\text { under a certain fare initiative, which may } \\
\text { include facility cost, fare collection cost, } \\
\text { etc. }\end{array}$ \\
\hline of cost & \\
\hline Change ofation
\end{tabular}

important factors because both have an impact on whether a fare initiative can be implemented smoothly. Based on such analysis, indices of feasibility of implementation, improvement of operation control, and change of cost are added. In current industry practice, most transit providers look at increasing ridership by gaining new riders. However, the proposed evaluation framework looks not only 
at new riders or riders who change to another mode as part of the change in ridership, but also takes into account existing riders increasing their use. That is to say, there are complicated relationships among indices of the change in ridership, change of revenue, and change of cost, which need to be analyzed carefully.

\section{Step 2. Determine Evaluation Set}

$$
V=\left\{v_{1}, v_{2}, \ldots, v_{n}\right\} \quad n=1,2, \ldots, 5
$$

where:

$$
\begin{array}{ll}
v_{1} & \text { represents "excellent"; } \\
v_{2} & \text { represents "good"; } \\
v_{3} & \text { represents "general"; } \\
v_{4} & \text { represents "need to be improved"; and } \\
v_{5} & \text { represents "need to be improved greatly." }
\end{array}
$$

Step 3. Obtain Weight Vector Using Analytic Hierarchy Process (i.e., AHP Method)

$$
A=\left\{a_{1}, a_{2}, \ldots, a_{m}\right\} \quad m=1,2, \ldots, 10
$$

where:

$$
\sum a_{i}=a_{1}+a_{2}+\ldots+a_{m}=1
$$




\section{Step 4. Determine Fuzzy Relation Matrix}

$$
R=\left(\begin{array}{l}
R_{1} \\
R_{2} \\
\vdots \\
R_{m}
\end{array}\right)=\left(\begin{array}{llll}
r_{11} & r_{12} & \ldots & r_{1 n} \\
r_{21} & r_{22} & \ldots & r_{2 \mathrm{n}} \\
\vdots & \vdots & \vdots & \vdots \\
r_{m 1} & r_{m 2} & \ldots & r_{m n}
\end{array}\right)
$$

where:

$$
\begin{aligned}
R=\left\{\begin{array}{rlll}
r_{i 1} & r_{i 2} & \ldots & r_{i n}
\end{array}\right\} & \text { is the } i \text { th row in the matrix } R, \text { and is the single fac- } \\
& \text { tor evaluation of the } i \text { th index } D_{i}, \text { which is a fuzzy } \\
& \text { subset on } V .
\end{aligned}
$$

\section{Step 5. Compute Evaluation Results Using And-Product Operator}

This step ensures that all factors will be considered completely, which will minimize the information loss. The "max principle" is adopted to obtain the final evaluation results:

$$
B=A \circ R\left\{e_{j}\right\}=\left\{e_{1}, e_{2}, e_{3}, e_{4}, e_{5}\right\}
$$

where:

$$
\begin{aligned}
& e_{1} \quad \text { reflects the degree that evaluation results belong to "excellent"; } \\
& e_{2} \quad \text { reflects the degree that evaluation results belong to "good"; } \\
& e_{3} \quad \text { reflects the degree that evaluation results belong to "general"; } \\
& e_{4} \quad \text { reflects the degree that evaluation results belong to "need to be } \\
& \text { improved"; and } \\
& e_{5} \quad \text { reflects the degree that evaluation results belong to "need to be } \\
& \text { improved greatly." }
\end{aligned}
$$

\section{Characteristics of the Proposed Evaluation Framework}

The proposed fare initiative fuzzy comprehensive evaluation process is summarized in the Figure 2. 


\section{Figure 2. Fare Initiative Fuzzy Comprehensive Evaluation Process}

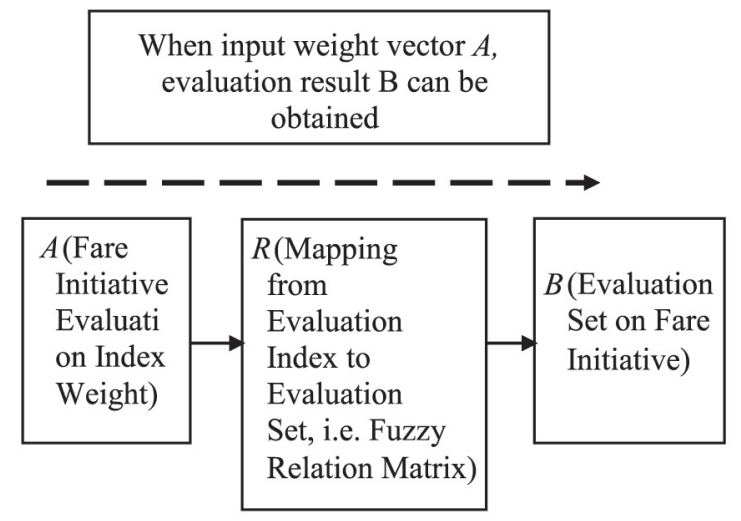

As stated earlier, the AHP is based on three steps: (1) decomposition of the decision problem and constructing hierarchies, (2) comparative judgement of the decision elements, and (3) synthesis of priorities. The AHP is used to handle both tangible and intangible factors and subfactors affecting fare decision making. In the proposed framework, AHP is used effectively to establish a hierarchical structure by decomposing the complex fare decision-making problem into a hierarchy of interrelated decision elements (i.e., fare evaluation indices). At the same time, the relative importance (weights) of all decision elements (i.e., weight vector $A$ ) can be explicitly captured and revealed through pair-wise comparison according to the specific scales. The proposed method combines the advantages of both multiple criteria fuzzy comprehensive evaluation and AHP, which treats the fare initiative evaluation as a multiple criteria decision, allowing decision-makers to objectively choose the fare initiative based on a comprehensive set of information.

\section{Relationship between Elasticity Theories versus Proposed Framework}

The fare elasticity-based evaluation approach is developed from transportation economics, which analyzes how fare changes impact transit ridership and revenue. This method, however, limits its application to the transit sector. Many exterior factors, such as social equity, affordability, convenience, and political acceptability, are not considered. Therefore, transit pricing decisions based on the elasticity analysis are not complete. Specifically, when the historical data needed for determining the fare elasticity is not all available and the industry standard such as Simpson-Curtin formula is adopted, the applicability and accuracy of the fare 
elasticity assessment is questionable. In view of the important role of transit in the overall transportation system, there is a need to put transit pricing decisions into a wider context.

As presented earlier, the fare initiative evaluation is an impact analysis process that involves value judgment from technological, socioeconomic, environmental, and political perspectives. The proposed fuzzy comprehensive evaluation combined with AHP is a more robust and flexible model designed to solve transit pricing decision problems involving multiple factors. Under most conditions, a fare elasticity analysis can provide index values for input to the fuzzy comprehensive evaluation combined with AHP. Therefore, traditional fare elasticity analysis and multiple criteria fuzzy comprehensive evaluation combined with AHP are not competitive but complementary.

\section{Case Study for Beijing}

Under the current fare initiative in Beijing, it is difficult to integrate different transportation resources fully and effectively. In turn, it is hard to gauge a reasonable relationship between transportation supply and demand, resulting in operation deficiency and incompetency in market competition and in the burden of subsidy on the government. While Beijing officials are pushing fare integration and price reform from technological and institutional aspects, they lack the objective and comprehensive evaluation tools to help them make decisions regarding different fare alternatives. This article provides a fuzzy comprehensive evaluation framework for them to choose suitable alternatives effectively. Evaluation process and some results are presented below.

\section{Integrated Fare Pricing Initiative in Beijing}

Devising an integrated transit system in Beijing means developing multimodes (e.g., bus, subway, light rail, etc.) with enhanced transportation capacities and management structures. An integrated fare initiative must be based on the concept of an integrated transit system - that is, to determine a comprehensive and integrated fare structure and payment technology accepted by all participating parties by coordinating all the public transit organizations related to light rail, subway, and bus systems. The ultimate goal is to complete the "One Card" project. The initiative will eventually benefit public transit companies, government institutions, and citizens. From an industry perspective, the objective of a fare initiative is to increase revenues; from the public perspective, the goal is to provide better 
services to citizens. Government decision-makers strive to balance the interests of both industry and the public by improving services while minimizing the subsidy to the transit industry.

Three different integrated fare alternatives were designed according to the extent of integration and the price level of a one-month pass ticket. The current fare alternative offers the least integration because only several lines of buses and light rail can use smart cards (i.e., "one card") that can be used both on the bus and subway systems. Suppose that this alternative is $L$. In alternative $L$, a one-month pass ticket with a price lower than its cost is widely used. Then another two additional integrated alternatives, $L 1$ and $L 2$, are designed. In $L 1$ and $L 2$, the one-card engineering project is fully deployed on all buses, light rail, and subway. $\ln L 1$, the price of the one-month pass ticket is adjusted 40 percent higher than that of alternative $L$. In $L 2$, the price of the one-month pass ticket is adjusted 200 percent higher than that of alternative $L$, and the fare revenue is close to the operation cost.

\section{Results from the Case Study for Beijing}

On the basis of the structured hierarchy shown in Figure 1, an AHP pair-wise comparison form is designed. Using direct interviewing and questioning of decision-makers from Beijing transit agencies, the priority comparison between each two evaluation criterion pair at the second level of the hierarchy is determined. Further, the priority comparison between each two indices at the third level of the hierarchy is determined in a similar way. The pair-wise comparisons are given in terms of how much one evaluation criterion $C_{x}$ is more important than another evaluation criterion $C_{y}$, or how much one index $D_{x}$ is more important than another index $D_{y}$, according to a nine-point scale of preference between the two elements shown in Table 2 designed by Saaty (2000). The obtained pair-wise comparison matrices with respect to an element (i.e., $U, C_{1}, C_{2}, C_{3}$ ) of the immediately higher level, which are the input data to compute weight $A$, are shown in Tables 3 through 6 . In these tables, the axes represent elements that will be pair-wise compared. For example, 3 in Table 3 means that $C_{1}$ is moderately preferred compared with $C_{2}$ according to the scale in Table 2. 
Table 2. Scale of Preference between Two Elements

\begin{tabular}{|c|l|l|}
\hline $\begin{array}{c}\text { Preference } \\
\text { Weights/Level of } \\
\text { Importance }\end{array}$ & \multicolumn{1}{|c|}{ Definition } & \multicolumn{1}{c|}{ Explanation } \\
\hline 1 & Equally preferred & $\begin{array}{l}\text { Two activities contribute equally to the } \\
\text { objective }\end{array}$ \\
\hline 3 & Moderately preferred & $\begin{array}{l}\text { Experience and judgment slightly favor } \\
\text { one activity over another }\end{array}$ \\
\hline 5 & Strongly preferred & $\begin{array}{l}\text { Experience and judgment stronglyor } \\
\text { essentially favor one activity over another }\end{array}$ \\
\hline 7 & Very strongly preferred & $\begin{array}{l}\text { An activity is strongly favored over } \\
\text { another and its dominance demonstrated } \\
\text { in practice }\end{array}$ \\
\hline 9 & Extremely preferred & $\begin{array}{l}\text { The evidence favoring one activity over } \\
\text { another is of the highest degree possible } \\
\text { of affirmation }\end{array}$ \\
\hline $2,4,6,8$ & Intermediates values & $\begin{array}{l}\text { Used to represent compromise between } \\
\text { the preferences listed above }\end{array}$ \\
\hline Reciprocals & Reciprocals for inverse comparison \\
\hline
\end{tabular}

Table 3. Pair-Wise Comparison Matrix $(U-C)$

\begin{tabular}{|c|c|c|c|}
\hline$U$ & $C_{1}$ & $C_{2}$ & $C_{3}$ \\
\hline$C_{1}$ & 1 & 3 & $1 / 2$ \\
\hline$C_{2}$ & $1 / 3$ & 1 & $1 / 2$ \\
\hline$C_{3}$ & 2 & 2 & 1 \\
\hline
\end{tabular}

Table 4. Pair-Wise Comparison Matrix $\left(C_{1}-D\right)$

\begin{tabular}{|c|c|c|c|}
\hline$C_{1}$ & $D_{1}$ & $D_{2}$ & $D_{3}$ \\
\hline$D_{1}$ & 1 & 3 & $1 / 5$ \\
\hline$D_{2}$ & $1 / 3$ & 1 & $1 / 6$ \\
\hline$D_{3}$ & 5 & 6 & 1 \\
\hline
\end{tabular}


Table 5. Pair-Wise Comparison Matrix $\left(C_{2}-D\right)$

\begin{tabular}{|c|c|c|c|}
\hline$C_{2}$ & $D_{4}$ & $D_{5}$ & $D_{6}$ \\
\hline$D_{4}$ & 1 & 5 & 4 \\
\hline$D_{5}$ & $1 / 5$ & 1 & 3 \\
\hline$D_{6}$ & $1 / 4$ & $1 / 3$ & 1 \\
\hline
\end{tabular}

Table 6. Pair-Wise Comparison Matrix $\left(C_{3}-D\right)$

\begin{tabular}{|c|c|c|c|c|}
\hline$C_{3}$ & $D_{7}$ & $D_{8}$ & $D_{9}$ & $D_{10}$ \\
\hline$D_{7}$ & 1 & 1 & 5 & 3 \\
\hline$D_{8}$ & 1 & 1 & 3 & 2 \\
\hline$D_{9}$ & $1 / 5$ & $1 / 3$ & 1 & 2 \\
\hline$D_{10}$ & $1 / 3$ & $1 / 2$ & $1 / 2$ & 1 \\
\hline
\end{tabular}

For this study, the weight computing procedure based on the mathematical principle of AHP is developed in Matlab language. The calculated weight vector $A$ is obtained as:

$$
\begin{aligned}
A= & \{0.0686,0.0311,0.2529,0.1147,0.0351,0.0179, \\
& 0.2018,0.1581,0.0640,0.0558\}
\end{aligned}
$$


Figure 3 shows the final weight $A$ outputted by the compiled Matlab procedure.

\section{Figure 3. The Final Weight Graph}

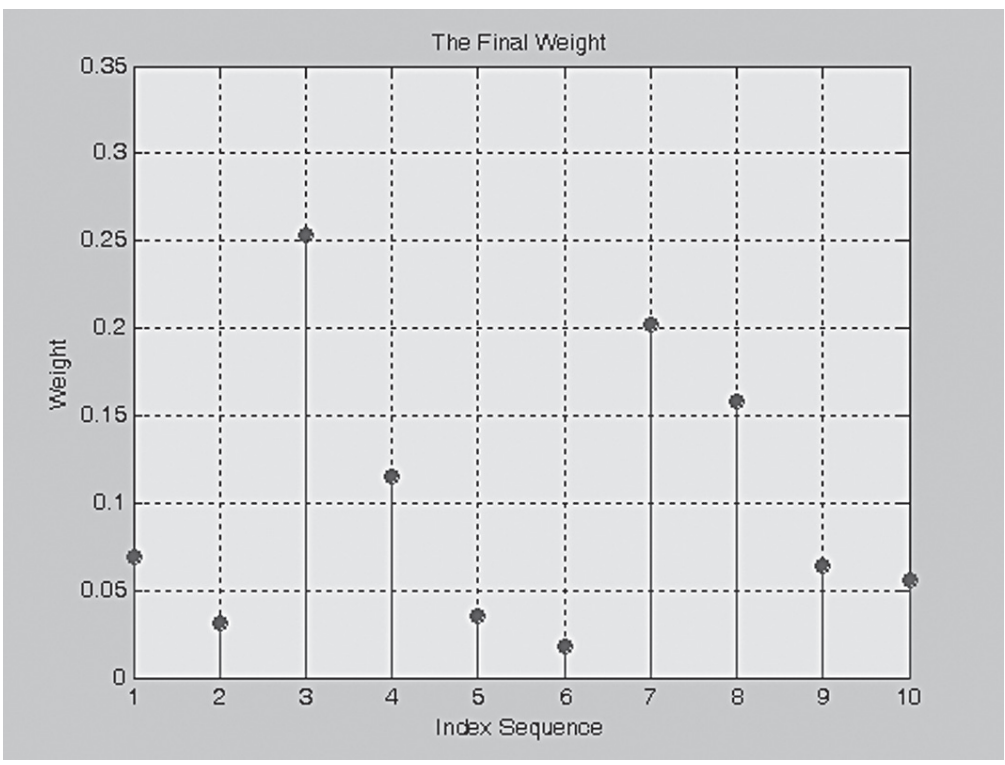

Next, a fuzzy relation questionnaire is designed to obtain the $R$. In the questionnaire, the first section is about the fare initiative description. The fare alternatives $L, L 1$, and $L 2$ are described in detail, as shown in Table 7. 
Table 7. Profile of Integrated Fare Alternatives

\begin{tabular}{|c|c|c|c|}
\hline & Fare Alternative L & Fare Alternative L1 & Fare Alternative L2 \\
\hline - Fare strategies & $\begin{array}{l}\text { There are no diversified } \\
\text { fare strategies. Main fare } \\
\text { strategies include single } \\
\text { ticket. Fare of intracity } \\
\text { bus line is } 1 \text { yuan. Fare } \\
\text { of suburb bus line is } 1 \\
\text { yuan within } 12 \\
\text { kilometers. Fare of } \\
\text { urban rail transit is } 3 \\
\text { yuan. }\end{array}$ & $\begin{array}{l}\text { - } \quad \text { Fare strategies are } \\
\text { similar to those of } \\
\text { fare alternative } L .\end{array}$ & $\begin{array}{l}\text { - Fare strategies are } \\
\text { similar to those of fare } \\
\text { alternative } L \text {. }\end{array}$ \\
\hline $\begin{array}{l}\text { - Main fare } \\
\text { category }\end{array}$ & $\begin{array}{l}\text { Main fare category is } \\
\text { general ticket and one- } \\
\text { month pass ticket. One- } \\
\text { month pass bus ticket is } \\
30 \text { to } 40 \text { yuan and } \\
\text { unlimited use. One- } \\
\text { month pass subway } \\
\text { ticket is } 50 \text { yuan and } \\
\text { unlimited use. These } \\
\text { tickets are too cheap to } \\
\text { cover the fare cost. }\end{array}$ & $\begin{array}{l}\text { Main fare category is } \\
\text { general ticket and } \\
\text { one-month pass } \\
\text { ticket. Price of } \\
\text { general ticket is } \\
\text { similar to that of } \\
\text { alternative } L \text {. One- } \\
\text { month pass bus ticket } \\
\text { is increased to } 40 \text { to } \\
50 \text { yuan and limited } \\
\text { use. One-month pass } \\
\text { subway ticket is } 65 \\
\text { yuan and limited use. } \\
\text { These are still not } \\
\text { enough to cover the } \\
\text { fare cost. }\end{array}$ & $\begin{array}{l}\text { Main fare category is } \\
\text { general ticket and } \\
\text { one-month pass ticket. } \\
\text { Price of general ticket } \\
\text { is similar to that of } \\
\text { alternative } L \text {. One- } \\
\text { month pass bus ticket } \\
\text { is increased to } 90 \text { to } \\
120 \text { yuan and limited } \\
\text { use. One-month pass } \\
\text { subway ticket is } 150 \\
\text { yuan and limited use. } \\
\text { These tickets are close } \\
\text { to covering the fare } \\
\text { cost. }\end{array}$ \\
\hline $\begin{array}{l}\text { Fare } \\
\text { collection and } \\
\text { sharing } \\
\text { method }\end{array}$ & $\begin{array}{l}\text { Both paper ticket and } \\
\text { smart card suitable for } \\
\text { bus and urban rail transit } \\
\text { are used. But the smart } \\
\text { card is not widely used. } \\
\text { Only two lines of the } \\
\text { total four urban rail } \\
\text { transit lines and more } \\
\text { than } 10 \text { percent of bus } \\
\text { system can use smart } \\
\text { cards. Fare is easy to } \\
\text { distinguish and share. }\end{array}$ & $\begin{array}{l}\text { Automatic fare } \\
\text { collection system and } \\
\text { smart cards will be } \\
\text { used on all buses, } \\
\text { light rail, and } \\
\text { subway. Fare is } \\
\text { shared using the data } \\
\text { from/to automatic } \\
\text { fare collection } \\
\text { system. }\end{array}$ & $\begin{array}{l}\text { Automatic fare } \\
\text { collection system and } \\
\text { smart cards will be } \\
\text { used on all buses, } \\
\text { light rail, and subway. } \\
\text { Fare is shared using } \\
\text { the data from/to } \\
\text { automatic fare } \\
\text { collection system. }\end{array}$ \\
\hline $\begin{array}{l}\text { The amount } \\
\text { of the } \\
\text { customer } \\
\text { discount when } \\
\text { using multiple } \\
\text { operators }\end{array}$ & $\begin{array}{l}\text { One-month pass ticket } \\
\text { used for both bus and } \\
\text { urban rail transit is } 80 \\
\text { yuan. The amount of the } \\
\text { ticket is controlled in } \\
\text { low ratio. }\end{array}$ & $\begin{array}{l}\text { One-month pass } \\
\text { ticket used for both } \\
\text { bus and urban rail } \\
\text { transit is } 130 \text { yuan. } \\
\text { The amount of the } \\
\text { ticket is still } \\
\text { controlled in the } \\
\text { same low ratio. }\end{array}$ & $\begin{array}{l}\text { One-month pass ticket } \\
\text { used for both bus and } \\
\text { urban rail transit is } \\
250 \text { yuan. The amount } \\
\text { of the ticket is still } \\
\text { controlled in the same } \\
\text { low ratio. }\end{array}$ \\
\hline $\begin{array}{l}\text { - } \begin{array}{l}\text { Change of } \\
\text { operation cost }\end{array}\end{array}$ & $\begin{array}{l}\text { Bus operation cost is } \\
21.7 \text { billion in } 2001 \text {. } \\
\text { Urban rail transit } \\
\text { operation cost was } 14.1 \\
\text { billion in } 2001 \text {. }\end{array}$ & $\begin{array}{l}\text { Bus operation cost } \\
\text { and urban rail transit } \\
\text { operation cost will } \\
\text { increase slightly. }\end{array}$ & $\begin{array}{l}\text { Bus operation cost } \\
\text { and urban rail transit } \\
\text { operation cost will } \\
\text { increase moderately. }\end{array}$ \\
\hline $\begin{array}{l}\text { - Impact on } \\
\text { revenue }\end{array}$ & $\begin{array}{l}\text { Main revenue for bus was } \\
14.6 \text { billion in } 2001 . \text { Main } \\
\text { revenue for urban rail } \\
\text { transit was } 7.3 \mathrm{~B} \text { in } 2001 \text {. }\end{array}$ & $\begin{array}{l}\text { Revenue will } \\
\text { decrease a little. }\end{array}$ & $\begin{array}{l}\text { - Revenue will decrease } \\
\text { moderately. }\end{array}$ \\
\hline
\end{tabular}




\begin{tabular}{|c|c|c|c|}
\hline & Fare Alternative L & Fare Alternative L1 & Fare Alternative L2 \\
\hline $\begin{array}{l}\text { - Change of } \\
\text { subsidy }\end{array}$ & $\begin{array}{l}\text { Average government } \\
\text { subsidy per year } \\
\text { between } 1996 \text { and } 2001\end{array}$ & $\begin{array}{l}\text { - Government subsidy } \\
\text { will decrease a little. }\end{array}$ & $\begin{array}{l}\text { Government subsidy } \\
\text { will decrease largely. }\end{array}$ \\
\hline $\begin{array}{l}\text { - Change of } \\
\text { ridership }\end{array}$ & $\begin{array}{l}\text { In } 2001, \text { ridership for } \\
\text { bus was } 34.1 \text { billion and } \\
\text { ridership for urban rail } \\
\text { transit was } 3.9 \text { billion. }\end{array}$ & $\begin{array}{l}\text { - } \quad \begin{array}{l}\text { Ridership will } \\
\text { decrease a little. }\end{array}\end{array}$ & $\begin{array}{l}\text { Ridership will } \\
\text { decrease moderately. }\end{array}$ \\
\hline $\begin{array}{l}\text { - Impact on } \\
\text { equity }\end{array}$ & $\begin{array}{l}\text { Price lower than cost } \\
\text { results in high subsidy } \\
\text { from government, which } \\
\text { is beneficial to low- } \\
\text { income community. }\end{array}$ & $\begin{array}{l}\text { Such price level } \\
\text { moderately affects } \\
\text { the benefit of low- } \\
\text { income community. }\end{array}$ & $\begin{array}{l}\text { - Such price level } \\
\text { largely affects the } \\
\text { benefit of low-income } \\
\text { community. }\end{array}$ \\
\hline
\end{tabular}

Table 8 shows the second section of the survey form.

Table 8. Survey Form on Beijing Fare Initiative
before/after Integration

\begin{tabular}{|c|c|c|c|c|c|c|}
\hline $\begin{array}{r}\text { Remark } \\
\text { Evalt }\end{array}$ & $\overbrace{\text { ation Index }}^{\text {Evaluation }}$ & Excellent & Good & General & $\begin{array}{l}\text { Needs } \\
\text { to be } \\
\text { Improved }\end{array}$ & $\begin{array}{l}\text { Needs } \\
\text { to be } \\
\text { Improved } \\
\text { Greatly } \\
\end{array}$ \\
\hline & Public Acceptance & & & & & \\
\hline $\begin{array}{l}\text { Cittizen- } \\
\text { related }\end{array}$ & Social Equity & & & & & \\
\hline & Convenience & & & & & \\
\hline & Change of Subsidy & & & & & \\
\hline Govt. & $\begin{array}{l}\text { Possibility of Modal } \\
\text { Integration }\end{array}$ & & & & & \\
\hline & Feasibility of Implementation & & & & & \\
\hline & Change of Revenue & & & & & \\
\hline Industry- & Change of Ridership & & & & & \\
\hline related & $\begin{array}{l}\text { Improvement of Operation } \\
\text { Control }\end{array}$ & & & & & \\
\hline & Change of Cost & & & & & \\
\hline
\end{tabular}


The third part of the questionnaire presents descriptions of indices. This portion was intended to help survey participants better understand the questions and to be able to answer the questions more easily. According to the description of the fare alternatives $L, L 1$, and $L 2$, the 10 indices are rated by the respondent according to five scales: excellent, good, general, need to be improved, and need to be improved greatly.

Two kinds of survey designs were compared in the process of choosing persons to be surveyed. One design process called for issuing questionnaires extensively, which would generate a good size of responses but yield a lower level of accuracy. The other design process called for issuing questionnaires to only those experts who are very familiar with transit fare pricing, which would result in a smaller sample size but one with a higher level of accuracy on the collected information. Considering the survey cost and expertise that the survey required, this survey was designed to focus on the experts only. While 21 surveyed responses may be a small sample statistically, if you consider the availability of experts on transit fare pricing in Beijing, the survey results are very representative. If, in the future, time and finance permit, the authors plan to conduct more extensive surveys. According to each index, its probabilities belonging to each of the five scales were statistically calculated, all of which construct the fuzzy relation matrix $R, R 1$, and $R 2$ as follows:

$$
R=r_{i j}=\left(\begin{array}{lllll}
0.095 & 0.571 & 0.286 & 0.048 & 0.000 \\
0.143 & 0.429 & 0.238 & 0.190 & 0.000 \\
0.048 & 0.238 & 0.429 & 0.286 & 0.000 \\
0.095 & 0.190 & 0.619 & 0.095 & 0.000 \\
0.000 & 0.238 & 0.381 & 0.333 & 0.048 \\
0.048 & 0.524 & 0.381 & 0.048 & 0.000 \\
0.095 & 0.190 & 0.333 & 0.333 & 0.048 \\
0.095 & 0.238 & 0.381 & 0.286 & 0.000 \\
0.143 & 0.095 & 0.333 & 0.429 & 0.000 \\
0.000 & 0.333 & 0.381 & 0.286 & 0.000
\end{array}\right)
$$




$$
R 1=r 1_{i j}=\left(\begin{array}{lllll}
0.238 & 0.476 & 0.238 & 0.048 & 0.000 \\
0.286 & 0.571 & 0.143 & 0.000 & 0.000 \\
0.381 & 0.190 & 0.381 & 0.048 & 0.000 \\
0.095 & 0.524 & 0.286 & 0.095 & 0.000 \\
0.190 & 0.571 & 0.238 & 0.000 & 0.000 \\
0.238 & 0.429 & 0.238 & 0.095 & 0.000 \\
0.095 & 0.714 & 0.190 & 0.000 & 0.000 \\
0.190 & 0.619 & 0.143 & 0.048 & 0.000 \\
0.286 & 0.619 & 0.095 & 0.000 & 0.000 \\
0.048 & 0.571 & 0.286 & 0.095 & 0.000
\end{array}\right)
$$

$$
R 2=r 2_{i j}=\left(\begin{array}{ccccc}
0.048 & 0.238 & 0.333 & 0.143 & 0.238 \\
0.095 & 0.190 & 0.381 & 0.286 & 0.048 \\
0.143 & 0.333 & 0.524 & 0.000 & 0.000 \\
0.190 & 0.476 & 0.286 & 0.048 & 0.000 \\
0.048 & 0.333 & 0.286 & 0.286 & 0.048 \\
0.048 & 0.476 & 0.333 & 0.143 & 0.000 \\
0.095 & 0.238 & 0.238 & 0.333 & 0.095 \\
0.095 & 0.190 & 0.286 & 0.381 & 0.048 \\
0.095 & 0.571 & 0.095 & 0.095 & 0.143 \\
0.000 & 0.333 & 0.286 & 0.286 & 0.095
\end{array}\right)
$$

Finally, the evaluation results on the fare alternative $L, L 1$, and $L 2$ are calculated using "And-product operator." As for $L: B=A \circ R=\left\{\begin{array}{l}0.07820 .25310 .3967 \\ 0.0 .030\end{array}\right.$ $0.26070 .0113\}$. According to the "max principle," the evaluation with the largest value of $e_{j}$ is regarded as the result of the evaluation. That is, the fare initiative before integration $L$ is evaluated as "general" because the largest value of $e_{3}$ is 0.3967 . As for $L 1: B 1=A \circ R 1=\{0.21370 .49990 .24560 .04080 .0000\}$. According to the same principle, the fare initiative after integration $L 1$ is evaluated as "good" because the largest value of $e_{2}$ is 0.4999 . As for $L 2: B 2=A \circ R 2$

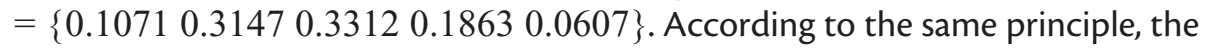
fare initiative after integration $L 1$ is evaluated as "general" because the largest value of $e_{3}$ is 0.3312 . 


\section{Conclusions}

In the process of integrating transportation resources, making a reasonable transit pricing decision is a challenge. An unreasonable transit pricing alternative leads to more trips using private cars, a large deficit, and a lack of competitiveness for transit corporations, resulting in heavy financial pressures on the government. Fare evaluation still remains one of the most controversial issues facing fare-regulating agencies. In this article, an approach using multiple criteria fuzzy comprehensive evaluation combined with AHP was proposed to deal with a fare evaluation. Three different integrated fare initiatives with different extents of integration and different price levels of a one-month pass ticket were analyzed. The result shows that the fare alternative $L 1$ is better than other fare alternatives, which means that the price level of a one-month pass ticket should be increased, while it recommended that its price cannot be increased to the level that is close to the operation cost. This case study also shows that the proposed framework is a practical and efficient way for the fare evaluation.

\section{Acknowledgments}

The authors acknowledge that this article was prepared based on the projects of National Natural Science Foundation of China (50208002), "Talent Building" Foundation of Beijing Jiaotong University (YSJ04001), and Postdoctoral Science Foundation of China (2002031036). 


\section{References}

Atthirawong, W., and B. MacCarthy. 2002. An application of the analytical hierarchy process to international location decision making. The 7th Annual International Manufacturing Symposium:1-18.

Curtin, J. F. 1968. Effect of fares on transit riding. Highway Research Record 213: 8-29.

Fleishman, D., N. Shaw, A. Joshi, and R. Freeze. 1996. Fare policies, structures and technologies. TCRP Report 10. Federal Transit Administration, Washington, DC.

Li, J., G. Zong, Y. Zhang, N. Ma, L. Zhao, and S. Yang. 2004. Fare structure and policy of urban public transportation in Beijing City. Unpublished report, Beijing University of Technology, Beijing: Beijing Economic and Social Development Research Institute.

Lu, Y. 2004. Research on fare pricing policy of urban mass transit and its supporting technology. B.S. Thesis. School of Traffic and Transportation, Beijing Jiaotong University, Beijing, China.

Ma, Y., Y. Sun, and H. Chen. 1999. The application of fuzzy comprehensive evaluation to test program analysis. 1999 IEEE International Conference Proceedings, IEEE Computer Society: 406-411.

Ouyang, M., W. Wang, and Y. Zhang. 2002. A fuzzy comprehensive evaluation based on distributed intrusion detection. Proceedings of the First International Conference on Machine Learning and Cybernetics: 281-284.

Saaty, T. L. 1980. The analytic hierarchy process: Planning, priority setting, resource allocation New York: McGraw-Hill.

Saaty, T.L. 2000. Fundamentals of decision making and priority theory. 2nd ed. Pittsburgh, PA: RWS Publications.

Todd, L. 2004. Transit price elasticities and cross-elasticities. Journal of Public Transportation 7: 37-58. 


\section{About the Authors}

XUMEI CHen (chenxumei@jtys.bjtu.edu.cn) is an associate professor of transportation planning and traffic management at Beijing Jiaotong University in Beijing, China. Her research focuses on travel demand forecasting and modeling, network planning of urban rail transit, integrated transit system management and operation, and industry policy of transportation.

LEI YU (yu_lx@tsu.edu) is a tenured professor at Texas Southern University and Changjiang scholar of Beijng Jiaotong University. His research focus is on large network modeling, intelligent transportation systems, and transport and the environment. He has the experience with directing more than 30 federal, state, and local projects and has published more than 100 scientific papers and reports.

Guoxin Lin (gxlin_2008@163.com) is a graduate research assistant at the School of Traffic and Transportation, Beijing Jiaotong University in Beijing, China. His research interests include rapid transit, urban rail transit systems, and intelligent transportation systems. 